\title{
KADAR ALKOHOL PADA MINUMAN TUAK DESA SANDA KECAMATAN PUPUAN KABUPATEN TABANAN BALI MENGGUNAKAN METODE KROMATOGRAFI GAS
}

\author{
(ALCOHOL CONCENTRATION ON TUAK BEVERAGES OF SANDA VILLAGE, PUPUAN \\ DISTRICT, TABANAN REGENCY OF BALI USING GAS CHROMATOGRAPHY METHOD)
}

\author{
I WAYAN TANJUNG ARYASA ${ }^{1 *}$, NI PUTU RAHAYU ARTINI ${ }^{1}$, DESAK PUTU RISKY V.A. ${ }^{1}$, \\ I MADE DWI HENDRAYANA ${ }^{1}$ \\ ${ }^{1}$ Program Studi Teknologi Laboratorium Medik, Institut Ilmu Kesehatan Medika Persada Bali
}

\begin{abstract}
Abstrak: Alkohol adalah cairan transparan yang dapat diperoleh dari fermentasi karbohidrat dan ragi, muda menguap, dapat bercampur dengan air, eter atau kloroform. Salah satu minuman beralkohol adalah minuman yang yang pembuatannya masih tradisional adalah tuak. Tuak mengandung alkohol dengan kadar 4\%. Konsumsi alkohol memiliki dampak besar dan kompleks pada penyakit kardiovaskular.Alkohol dapat merusak susunan saraf pusat dan menyebabkan ketergantungan atau alkoholisme. Pada kadar yang tinggi melebihi 55\% etanol dapat menyebabkan keracunan bahkan kematian.Oleh karena itu perlu dikembangkan metode analisis kandungan alkohol yang sederhana dan selektif serta tidak memerlukan biaya yang mahal saat pengujian serta tidak memerlukan waktu yang lama dalam mendapatkan hasilnya.Dalam penelitian ini dipilih metode kromatografi gas karena dengan metode ini proses analisis dilakukan cepat biasanya dalam hitungan menit, lebih efisien, resolusinya tinggi, sensitif, dapat mendeteksi dalam ukuran ppm (part per million) bahkan ppb (part perbillion). Uji lain yang menunjuang penelitian ini adalah uji kadarkeasaman dan uji organoleptik. Hasil dari kadar etanol pada minuman tuak aren adalah sebagai berikut 4,839\%; 5,076\%; 5,233\%; 5,173\%; 4,971\%; 4,954\% dan 4,927\%.Sedangkan untuk nilai $\mathrm{pH}$ pada tuak yang berhubungan dengan kadar keasaman diperoleh nilai $\mathrm{pH}$ rata-rata sebesar 4. Sedangkan dari hasil uji organoleptik, tuak aren yang paling disukai baik dari segi rasa, warna, dan aroma adalah tuak aren dengan waktu penyimpanan pada hari pertama.
\end{abstract}

Kata kunci: Kromatografi Gas, Organoleptik, pH, Tuak

\begin{abstract}
Alcohol is a transparent liquid that can be obtained from the fermentation of carbohydrates and yeast, yawn yeast, can be mixed with water, ether or chloroform. One of the alcoholic beverages that is still traditional is tuak, tuak contains alcohol with $4 \%$ content. Alcohol can damage the central nervous system and cause dependence or alcoholism. At high levels exceeding 55\% ethanol can cause poisoning and even death. Therefore it is necessary to develop a simple and selective method of alcohol content analysis and does not require a high cost during testing and does not require a long time in getting the results. In this research, gas chromatography method is chosen because with this method, the analysis process is done quickly, usually in minutes, more efficient, high resolution, sensitive, can detect in ppm (part per million) and even ppb (part per billion). Other tests that support this research are acidity test and organoleptic test. The result of ethanol content in palm tuak is as follows 4.839\%; 5.076\%; 5.233\%; 5.173\%; 4.971\%; 4.954\% and 4.927\%. For the pH value at the tuak, the average $\mathrm{pH}$ value is 4 . While from the organoleptic test result, palm sugar is the most favorable both in terms of taste, color, and aroma is palm tuak with the time of storage on the first day.
\end{abstract}

Keywords: Gas Chromatography, Oganoleptic, pH, Tuak

\section{PENDAHULUAN}

Alkohol adalah cairan transparan yang dapat diperoleh dari fermentasi karbohidrat dan ragi, mudah menguap, dapat bercampur dengan air, eter atau kloroform (Iskandar, 2012). Peraturan Presiden nomor 74 tahun 2013 menyatakan bahwa minuman beralkohol merupakan minuman yang mengandung etil alkohol atau etanol $\left(\mathrm{C}_{2} \mathrm{H}_{5} \mathrm{OH}\right)$ yang diproses dengan cara fermentasi dengan atau tanpa destilasi dari bahan hasil pertanian. Tuak adalah minuman beralkohol tradisional di daerah
Sumatera Utara, terutama pada Suku Batak Toba, yang mengandung alkohol dengan kadar $4 \%$ (Ilyas, 2013). Berdasarkan keputusan dan peraturan yang telah ditetapkan, maka tuak dapat digolongkan sebagai salah satu jenis minuman keras. Dengan demikian, tuak dapat digolongkan sebagai minuman keras golongan A. Jika dibandingkan dengan minuman alkohol import, seperti whisky atau brandy yang mengandung kadar alkohol sebesar 20\%-50\% (golongan C) (Mahkamah Agung, 2012), kadar alkohol tuak jauh lebih rendah.

\footnotetext{
* email korespondensi: tanjung.aryasa@gmail.com
} 
Salah satu minuman beralkohol yang pembuatannya masih tradisional adalah tuak, tuak mengandung alkohol dengan kadar 4\% (Ilyas, 2013). Pada penelitian yang sudah dilakukan kadar etanol tuak aren hasil penyimpanan pada hari pertama hingga hari kelima terus mengalami peningkatan yaitu $8,1512 \%, 8,234 \%, 9,117 \%$, $10,6214 \%$, dan $11,615 \%$ (Trisna Pradnyandari dkk, 2017). Dalam kehidupan sehari-hari tuak selain sebagai minuman beralkohol juga dimanfaatkan di dalam upacara-upacara keagamaan umat Hindu.Menurut Sri Arnawi (Suwena, 2017) dalam upacara keagamaan tuak dimanfaatkan untuk metabuh (persembahyangan), yang tidak saja disujudkan kehadapan Tuhan Yang Maha Esa/Ida Sang Hyang Widhi Wasa, namun yang utama metabuh juga sebagai pelengkap di dalam upacara mecaru (korban suci kepada bhuta kala). Hal ini dimaksudkan untuk mewujudkan keharmonisan di alam semesta, yaitu antara bhuana alit (tubuh manusia) dengan bhuana agung (alam semesta). Selain dimanfaatkan dalam upacara keagamaan tuak juga dapat dipergunakan sebagai bahan membuat gula (gula Bali) dan sebagai bahan baku minuman keras yaitu minuman arak yang pembuatannya melalui penyulingan tuak tersebut sehingga menghasilkan arak (Suwena, 2017).

Konsumsi alkohol memiliki dampak besar dan kompleks pada penyakit kardiovaskular. Minum kera kronis dan irreguler berdampak buruk pada kategori penyakit kardiovaskular yang paling utamasedangkan minum ringan sampai sedang telah dikaitkan dengan efek menguntungkan pada penyakitjantung iskemik dan stroke iskemik.Efek merugikan dan menguntungkan dari konsumsi alkohol telah terjadi dikuatkan denganbagian biokimia.Dampak konsumsi alkohol terhadap penyakit kardiovaskularharus dievaluasi dalam konteks efek alkohol lainnya terhadap kesehatan (J. Rehm dan M. Roerecke, 2017).Alkohol dapat merusak susunan saraf pusat dan menyebabkan ketergantungan atau alkoholisme.Pada kadar yang tinggi melebihi 55\% etanol dapat menyebabkan keracunan bahkan kematian (Suaniti, 2012).

Oleh karena itu, perlu dikembangkan suatu metode analisis untuk penentuan kandungan alkohol yang sederhana dan selektif serta tidak memerlukan biaya yang mahal saat pengujian serta tidak memerlukan waktu yang lama dalam mendapatkan hasilnya.Penentuan kandungan alkohol sendiri sebelumnya sudah dikembangkan dengan berbagai metode analisis. Ada beberapa metode untuk penentuan kandungan alkohol, baik untuk alkohol itu sendiri atau berupa campuran dalam sampel formula dan sampel biologi, yaitu metode spektrofotometri, metode densitometri dan metode refraktometri.

Dalam penelitian ini dipilih metode kromatografi gas karena dengan metode ini proses analisis dilakukan cepat biasanya dalam hitungan menit, lebih efisien, resolusinya tinggi, sensitif, dapat mendeteksi dalam ukuran ppm (part per million) bahkan ppb (part per billion), analisis secara kuantitatif dengan akurasi yang tinggi, memerlukan sampel dalam jumlah kecil, umumnya dalam $\mu$, handal dan relatif sederhana dan tidak mahal serta dapat melakukan pemisahan secara dinamis, identifikasi semua jenis senyawa organik yang mudah menguap, kepekaan tinggi, serta dapat melakukan analisis kualitatif dan kuantitatif senyawa dalam campuran, dan sampel yang digunakan untuk analisis relatif sedikit (McNair dan Miller, 2009).

Permasalahan pada penelitian adalah untuk mengetahui kandungan alkohol pada sampel tuak aren dari Desa Sanda, Kecamatan Pupuan, Kabupaten Tabanan.Sebagai informasi awal kandungan alkohol tuak.Sehingga tujuan dari penelitian ini adalah penggunaan metode yang telah diinvestigasi secara ekonomi, sederhana dan ramah lingkungan untuk penentuan kandungan alkohol dengan menggunakan kromatografi gas (McNair dan Miller, 2009).

\section{BAHAN DAN METODE}

Bahan. Bahan-bahan yang digunakan dalam penelitian ini adalah aquabidest, tuak aren dari Desa Sanda, Kecamatan Pupuan, Kabupaten Tabanan, etanol $96 \%$ (E-Merck p.a.), isopropanol (E-Merckp.a.), etil asetat (E-Merck p.a.) dan diklorometan (E-Merck p.a).

Metode. Jenis penelitian ini termasuk dalam rancangan eksperimen semu (quasi experiment design).Lokasi penelitian dilakukan di Laboratorium UPT Analitik Universitas Udayana. Pengukuran kadar etanol dan $\mathrm{pH}$ pada tuak aren dilakukan di Laboratorium UPT Analitik Universitas Udayana. Penelitian ini dilaksanakan pada bulan November2017 sampai Januari 2018.Populasi pada penelitian ini adalah tuak aren yang berada di Desa Sanda, Kecamatan Pupuan,Kabupaten Tabanan.Penelitian ini dilakukan dengan menggunakan tujuh sampel sehingga diperoleh jumlah data sebanyak tujuh data. Sampel sesuai kriteria yang sudah ditetapkan yaitu tuak aren segar yang baru disadap dan siap dikonsumsi. Sampel tuak aren disimpan pada suhu ruang $\left(24-30^{\circ} \mathrm{C}\right)$ pada hari pertama, kedua, ketiga, 
keempat, kelima, keenam dan ketujuh.Penelitian dilakukan dengan menilai karakteristik objektif dan subjektif tuak aren.

Penentuan Kadar Alkohol dengan Metode Kromatografi Gas (KG). Tuak diambil sebanyak $10 \mathrm{~mL}$ dan diencerkan ke dalam labu ukur $50 \mathrm{~mL}$ dengan aquabidest.Selanjutnya, didestilasi dengan seperangkat alat destilasi Small Kit Standar Sethingga diperoleh destilat sebanyak $75 \%$ dari volume awal.Destilat dipindahkan secara kuantitatif ke labu ukur $10 \mathrm{~mL}$, lalu tambahkan aquabidest hingga mencapai tanda batas.Selanjutnya sebagian dituangkan ke tabung evendoff dan siap untuk diinjeksikan ke dalam injector $G C$ dengan menggunakan micro syringe sebagai alat suntik ke injector GC.Larutan standar yang digunakan standar etanol $10 \%$ kemudian dibandingkan dengan larutan sampel dan larutan standar.

Pengukuran pH menggunakan pH meter. Masukkan alat pHmeter kedalam larutan sampel tuak untuk sampel tuak penyimpanan hari pertama, adalah tuak yang pertama kali diambil dari pohon aren, tuak penyimpanan hari kedua yaitu tuak yang telah dilakukan penyimpanan selama 24 jam setelah penyimpanan tuak hari pertama, tuak penyimpanan hari ketiga, adalah tuak yang telah dilakukan penyimpanan selama 48 jam setelah penyimpanan tuak hari pertama, tuak penyimpanan hari keempat adalah tuak yang telah dilakukan penyimpanan selama 72 jam setelah penyimpanan tuak hari pertama, tuak penyimpanan hari kelima adalah tuak yang telah dilakukan penyimpanan selama 96 jam setelahpenyimpanan tuak hari pertama, tuak penyimpanan hari keenam adalah tuak yang telah dilakukan penyimpanan selama 120 jam setelah penyimpanan tuak hari pertama dan tuak penyimpanan hari ketujuh adalah tuak yang telah dilakukan penyimpanan selama 144 jam setelah penyimpanan tuak hari pertama.

Uji Organoleptik Tuak. Pengujian organoleptik adalah pengujian yang didasarkan pada proses pengindraan. Pengindraan diartikan sebagai suatu proses fisio-psikologis, yaitu kesadaran atau pengenalan alat indra akan sifat-sifat benda karena adanya rangsangan yang diterima alat indra yang berasal dari benda tersebut.Pengindraan dapat juga berarti reaksi mental (sensation) jika alat indra mendapat rangsangan (stimulus). Reaksi atau kesan yang ditimbulkan karena adanya rangsangan dapat berupa sikap untuk mendekati atau menjauhi, menyukai atau tidak menyukai akan benda penyebab rangsangan. Kesadaran, kesan dan sikap terhadap rangsangan adalah reaksi psikologis atau reaksi subyektif.Pengukuran terhadap nilai / tingkat kesan, kesadaran dan sikap disebut pengukuran subyektif atau penilaian subyektif. Disebut penilaian subyektif karena hasil penilaian atau pengukuran sangat ditentukan oleh pelaku atau yang melakukan pengukuran.Sampel tuak diperlakukan dengan melihat warna, aroma dan rasa untuk sampel tuak penyimpanan hari pertama, adalah tuak yang pertama kali diambil dari pohon aren, tuak penyimpanan hari kedua yaitu tuak yang telah dilakukan penyimpanan selama 24 jam setelah penyimpanan tuak hari pertama, tuak penyimpanan hari ketiga, adalah tuak yang telah dilakukan penyimpanan selama 48 jam setelah penyimpanan tuak hari pertama, tuak penyimpanan hari keempat adalah tuak yang telah dilakukan penyimpanan selama 72 jam setelah penyimpanan tuak hari pertama, tuak penyimpanan hari kelima adalah tuak yang telah dilakukan penyimpanan selama 96 jam setelah penyimpanan tuak hari pertama, tuak penyimpanan hari keenam adalah tuak yang telah dilakukan penyimpanan selama 120 jam setelah penyimpanan tuak hari pertama dan tuak penyimpanan hari ketujuh adalah tuak yang telah dilakukan penyimpanan selama 144 jam setelah penyimpanan tuak hari pertama.

\section{HASIL DAN PEMBAHASAN}

Uji Organoleptik Tuak Aren. Penilaian karakteristik sampel tuak aren menggunakan uji organoleptik.Uji organoleptik pada sampel tuak aren.dilakukan pada sore hari dengan metode uji penerimaan yang meliputi rasa, warna, dan aroma tuak aren berdasarkan lama waktu penyimpanan.Diperoleh hasil yang dapat dilihat pada tabel 1.

Berdasarkan hasil penilaian uji organoleptik, tuak aren pada penyimpanan hari pertama memiliki rasa manis agak asam. Rasa manis tersebut disebabkan oleh kandungan sukrosa yang terdapat pada tuak aren yang dihasilkan proses fermentasi (Trisna Pradnyandari dkk, 2017).

Tuak aren pada penyimpanan hari kedua dan ketiga memiliki rasa asam. Rasa asam tersebut disebabkan oleh kecepatan fermentasi yang terjadi pada tuak sehingga kadar gula menurun, karena sebagian gula dirombak oleh enzim yang dihasilkan dari proses fermentasi menjadi asam dan alkohol. Hal ini menyebabkan tuak aren menjadi masam. Rasa tuak aren pada penyimpanan hari keempat dan kelimasemakin asam dan pada hari keenam dan ketujuh rasa dari tuak aren sudah mulai pahit (Trisna Pradnyandari dkk, 2017). 
Semakin lama penyimpanan maka kadar gula pada tuak akan semakin menurun sehingga rasa dari tuak akan semakin asam dan pahit. Perubahan warna dari tuak aren dari penyimpanan hari pertama hingga hari kelima tidak terlalu signifikan. Hanya warna tuak yang awalnya putih keruh berubah semakin pucat (kekuningan) selama proses penyimpanan. Warna putih keruh tersebut diperoleh dari pengawet alami tuak yaitu lau (sabut kelapa) (Trisna Pradnyandari dkk, 2017).

Pada hasil uji organoleptik, aroma tuak aren yang awalnya segar pada hari pertama mulai mengalami perubahan aroma menjadi asam pada penyimpanan hari kedua. Aroma asam tersebut disebabkan karena pada tuak yang difermentasi, mikroba proteolitik dan lipolitik tidak berkembang dengan baik karena konsentrasi alkohol dan asam yang lebih tinggi, sehingga aroma yang lebih dominan adalah aroma alkohol yang agak asam (Mussa, 2014). Aroma asam dari tuak aren semakin menyengat pada hari ketiga hingga hari keempat dan pada hari kelima aroma tuak aren menjadi agak busuk.Hal tersebut disebabkan oleh mikroba proteolitik pada tuak aren menghasilkan bau busuk dengan memecah protein dan komponen nitrogen, sedangkan mikroba lipolitik memecah serta menghidrolisa lemak dan fosfolipid sehingga menghasilkan bau tengik (Mussa, 2014).

Tabel 1

Penilaian Organoleptik Tuak Aren

\begin{tabular}{|c|c|c|c|c|}
\hline No & $\begin{array}{c}\text { Waktu } \\
\text { Penyimpanan } \\
\end{array}$ & Rasa & Warna & Aroma \\
\hline 1 & Hari I & Manis agak asam & Putih Agak Keruh & Segar \\
\hline 2 & Hari II & Asam & Putih Keruh & Asam \\
\hline 3 & Hari III & Asam & Putih Keruh & Asam agak menyengat \\
\hline 4 & Hari IV & Sangat asam & Putih sedikit kuning keruh & Asam agak menyengat \\
\hline 5 & Hari V & Sangat asam & Putih kekuningan & Asam sangat menyengat \\
\hline 6 & Hari VI & Asam agak Pahit & Kekuningan & Asam sangat menyengat \\
\hline 7 & Hari VII & Sangat Pahit & Kekuningan & Sangat busuk \\
\hline
\end{tabular}

Uji Kadar Etanol Tuak Aren. Hasil pemeriksaan kadar alkohol pada tuak aren pada penyimpanan hari pertama, hari kedua, hari ketiga, hari keempat, hari kelima, hari keenam dan hari dapat dilihat pada tabel berikut:

\begin{tabular}{clc}
$\begin{array}{c}\text { Tabel 2.Kadar Etanol Pada Variasi Waktu Penyimpanan } \\
\text { No. }\end{array}$ & \multicolumn{1}{c}{ Waktu } & $\begin{array}{c}\text { Kadar Etanol } \\
(\mathbf{\%})\end{array}$ \\
\hline $\mathbf{1}$ & Penyimpanan & 4,839 \\
$\mathbf{2}$ & Hari I & 5,076 \\
$\mathbf{3}$ & Hari III & 5,233 \\
$\mathbf{4}$ & Hari IV & 5,173 \\
$\mathbf{5}$ & Hari V & 4,971 \\
$\mathbf{6}$ & Hari VI & 4,954 \\
$\mathbf{7}$ & Hari VII & 4,927 \\
\hline
\end{tabular}

Kadar etanol pada tuak aren yang diukur berdasarkan lama penyimpanan mengalami peningkatan dan penurunan. Tuak aren dengan waktu penyimpanan pada hari pertama diperoleh kadar etanol sebesar 4,839\%. Tuak aren yang mengalami penyimpanan pada hari kedua memiliki kadar etanol sebesar 5,076\%. Jika dibandingkan dengan kadar etanol pada tuak aren dengan penyimpanan pada hari pertama terjadi peningkatan kadar etanol sebesar 0,237\%. Pada tuak aren yang mengalami penyimpanan dalam suhu ruang pada hari ketiga diperoleh kadar etanol sebesar $5,233 \%$. Dibandingkan dengan kadar etanol pada hari kedua terjadi peningkatan kadar etanol sebesar 0,157\%. Pada tuak aren yang mengalami penyimpanan dalam suhu ruang pada hari keempat diperoleh kadar etanol sebesar $5,173 \%$. Dibandingkan dengan kadar etanol pada hari ketiga terjadi penurunan kadar etanol sebesar $0,06 \%$. Tuak aren yang mengalami penyimpanan di suhu ruang pada hari kelima diperoleh kadar etanol sebesar 4,971\%. Dibandingkan dengan kadar etanol pada hari keempat terjadi penurunan kadar etanol sebesar $0,202 \%$. Tuak aren yang mengalami penyimpanan di suhu ruang pada hari keenam diperoleh kadar etanol sebesar 4,954\%. Dibandingkan dengan kadar etanol pada hari kelima terjadi penurunan kadar etanol sebesar 
$0,017 \%$. Tuak aren yang mengalami penyimpanan di suhu ruang pada hari ketujuh diperoleh kadar etanol sebesar 4,927\%. Dibandingkan dengan kadar etanol pada hari keenam terjadi penurunan kadar etanol sebesar $0,027 \%$. Terjadi penurunan kadar yang terjadi pada hari keempat, kelima, keenam dan ketujuh,hal tersebut dapat dijelaskan menurut Sari, dkk (2008), menyatakan bahwa lama fermentasi yang paling optimal untuk proses pembuatan etanol atau bioetanol adalah 3 hari. Jika fermentasi dilakukan lebih dari 3 hari, justru kadar alkoholnya dapat berkurang. Berkurangnya kadar alkohol disebabkan karena alkohol telah dikonversi menjadi senyawa lain, misalnya ester. Berdasarkan hasil penelitian tersebut dapat diketahui kadar etanol pada tuak aren yang telah mengalami penyimpanan dari hari pertama hingga hari ketujuh berkisar pada $4-5 \%$ sehingga tuak aren tersebut termasuk kedalam minuman keras golongan $\mathrm{A}$.

Pengaruh Keasaman Pada Tuak Aren. Hasil pemeriksaan keasaman pada tuak aren pada penyimpanan hari pertama, hari kedua, hari ketiga, hari keempat, hari kelima, hari keenam dan hari ketujuh dapat dilihat pada tabel 3 sebagai berikut:

Tabel 3.Nilai pH Tuak Aren

\begin{tabular}{cll}
\hline No. & Waktu Penyimpanan & $\mathbf{p H}$ \\
\hline $\mathbf{1}$ & Hari I & 3,7 \\
$\mathbf{2}$ & Hari II & 3,9 \\
$\mathbf{3}$ & Hari III & 4,0 \\
$\mathbf{4}$ & Hari IV & 4,2 \\
$\mathbf{5}$ & Hari V & 4,3 \\
$\mathbf{6}$ & Hari VI & 4,4 \\
$\mathbf{7}$ & Hari VII & 4,6 \\
\hline
\end{tabular}

Proses fermentasi dari tuak aren dipengaruhi oleh beberapa faktor yang salah satunya adalah $\mathrm{pH} . \mathrm{pH}$ tuak aren dengan waktu penyimpanan pada hari pertama, hari kedua, hari ketiga, hari keempat, kelima, keenam dan ketujuh memiliki $\mathrm{pH}$ rata-rata yaitu 4 . Hasil pengukuran $\mathrm{pH}$ tersebut menunjukkan tuak aren dengan waktu penyimpanan pada hari pertama, hari kedua, hari ketiga, hari keempat, hari kelima, hari keenam dan ketujuh berada dalam suasana asam.Dalam suasana asam tersebut hingga hari ketujuh pertumbuhan khamir masih berlangsung sehingga proses fermentasi masih terjadi. Pertumbuhan khamir dapat berlangsung baik pada suasana asam yaitu pada $\mathrm{pH} 4,0-4,55 . \mathrm{pH}$ tuak aren yang rendah dapat mengakibatkan dampak negatif bagi kesehatan gigi apabila dikonsumsi secara berkelanjutan(Prasetyo, 2005).

\section{SIMPULAN}

1. Kadar alkohol (etanol) tuak aren hasil penyimpanan pada hari pertama hingga hari ketujuh yaitu $4,839 \%$; 5,076\%; 5,233\%; $5,173 \% ; 4,971 \% ; 4,954 \%$ dan 4,927\%. Dari hasil nilai etanol tersebut, tuak aren termasuk kedalam minuman keras golongan A berdasarkan keputusan Mahkamah Agung No. 42 P/HUM/2012.
2. Nilai $\mathrm{pH}$ tuak aren dengan lama waktu penyimpanan pada hari pertama hingga hari kelima memiliki $\mathrm{pH}$ yang sama yaitu 4 . Dari hasil pengukuran $\mathrm{pH}$ tersebut menunjukkan tuak aren bersifat asam.

3. Dari hasil uji organoleptik, tuak aren yang paling disukai baik dari segi rasa, warna, dan aroma adalah tuak aren dengan waktu penyimpanan pada hari pertama.

\section{DAFTAR PUSTAKA}

Ilyas, S. 2013. Evaluasi Kualitas Spermatozoa Dan Jumlah Turunan Mencit (Mus musculus L.) (F1) Setelah Pemberian Tuak. Prosiding Semirata FMIPA Universitas Lampung.

Iskandar, Y. 2012. Penentuan Konsentrasi Alkohol dalam Tapai Ketan Hitam Secara Piknometri Berdasarkan Lama Waktu Fermentasi. Fakultas MIPA Universitas Padjadjaran Jatinangor, Bandung.

Mahkamah Agung. 2012. Putusan 42 $\mathrm{P} / \mathrm{HUM} / 2012$.

McNair, H.M., dan Miller,J.M. 2009. Basic Gas Chromatography. $2^{\text {nd }}$ Ed.United States of America: A John Wiley \& Sons, Inc. 
Mussa, R. 2014. Kajian Tentang Lama Fermentasi Nira Aren (Arenga pinnata) Terhadap Kelimpahan Mikroba dan Kualitas Organoleptik Tuak. Ambon: Universitas Pattimura.

Prasetyo. 2005. Keasaman Minuman Ringan Menurunkan Kekerasan Permukaan Gigi.tersedia

dalamhttp://www.journal.unair.ac.id/filerPD F/DNTJ-38-2-04.pdf diakses pada 9 Juni 2016.

Rehm, J., Roerecke, M., 2017.Cardiovascular effects of alcohol consumption, Trends in Cardiovascular Medicine, http://dx.doi.org/10.1016/j.tcm.2017.06.00 $\underline{2 .}$

Sari, I. M., Noverita Dan Yulneriwarni.2008. Pemanfaatan Jerami padi dan alang-alang dalam fermentasi etanol menggunakan kapang Trichoderma Viride dan khamir Saccharomycess cerevisiae.Vis Vitalis.5(2):55-62.
Suaniti, Ni Made. 2012. Analisis Fatty Acid Ethyl Ester Dengan Infra Red Dalam Darah Tikus Wistar Setelah Minum Alkohol Secara Akut. Jurnal Kimia (Journal Of Chemistry), [S.L.], Nov. 2012. Issn 1907-9850.

Suwena, Kadek Rai. 2017. Menjual Tuak (Alkohol Bali) Sebuah Pilihan (Tinjauan Dari Perspektif Sosial dan Ekonomi Masyarakat di Desa Datah).International Journal of Social Science and Businnes. Vol.1 (1) pp. 24-30.

Trisna Pradnyandari, A. A., Sri Dhyanaputri, I Gusti Ayu, Jirna I Nyoman. 2017. Kajian Karakteristik Objektif dan Subjektif Tuak Aren (Arenga pinnata) Berdasarkan Lama Waktu Penyimpanan, Meditory ISSN Online : 2549-1520, ISSN Cetak : 23381159, Vol. 5, No.1, Juni 2017 Hlm.1322,http://ejournal.poltekkes-denpasar.ac.id. 